\title{
Определение частотно-контрастной характеристики ИК объективов
}

\author{
В.В. Васильев, А.В. Вишняков, Г.Ю. Сидоров, В.А. Стучинский \\ Институт физики полупроводников им. А.В. Ржанова, Новосибирск, \\ 630090, пр. Академика Лаврентьева, 13 \\ тел: +7 (383) 330-10-82, факс:+7 (383) 330-10-82, эл. почта: vishn@isp.nsc.ru
}

DOI 10.34077/RCSP2021-54

Полная частотно-контрастная характеристика (ЧКХ) инфракрасного (ИК) матричного фотоприемника (МФ) равна произведению ЧКХ объектива на ЧКХ фотоприемной матрицы. Для выделения ЧКХ фотоприемной матрицы из полной ЧКХ надо знать ЧКХ объектива. Калибровка установки измерения пространственного разрешения МФ является важной частью измерительной процедуры. Помимо дифракции на апертуре объектива, его ЧКХ определяется также величиной аберраций.

В настоящей работе предложен метод определения ЧКХ ИК- объектива, в котором используется матричный ИК- фотоприемник совместно с помещенным на него напыленным на кремниевую подложку металлическим экраном с протравленными узкими апертурными щелями, ширина которых меньше ширины пятна Эйри. В этом случае пространственное разрешение апертурированного фотоприемника определяется шириной щелей. Результатом сканирования изображения выходной щели монохроматора апертурными щелями является функция рассеяния линии (ФРЛ). ИК- излучение, прошедшее через щели, дифрагирует, поглощается в абсорбере фотоприемника, и возникающие фотоносители детектируются $p$ - $n-$ переходами МФ. Суммарный фотосигнал всех пикселей при этом пропорционален потоку излучения, прошедшего через щель. Для измерения функции рассеяния точки (ФРТ) обычно используется ИК- детектор с небольшой шириной апертуры (меньше размера пятна Эйри) и нужного спектрального диапазона с освещением от АЧТ. При таком способе ИК- излучение является немонохроматическим, со спектром, распределенным в соответствии с распределением Планка вблизи длинноволновой границы фоточувствительности используемого детектора, и поэтому при измерениях необходимо использовать полосовой оптический фильтр. Интенсивность квазимонохроматического излучения на выходе монохроматора гораздо меньше, чем интенсивность излучения от АЧТ; поэтому

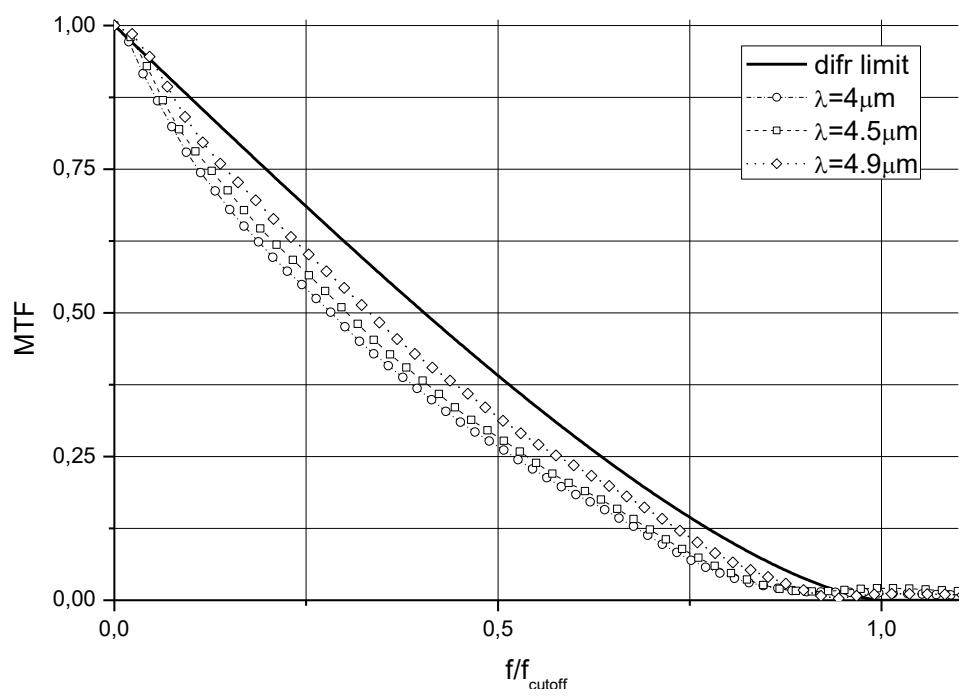

Рис. ЧКХ объектива диапазона 3-5 мкм на длинах волн $4,4.5$, и 4.9 мкм. Пространственная частота нормирована на $\mathrm{f}_{\text {cutoff }}=1 / \lambda \mathrm{F}$. Сплошной линией показан дифракционный предел. для увеличения сигнала выгодней использовать детекторы с линейчатой щелевой апертурой вместо точечной из-за большей площади щели, обеспечивающей большую интенсивность регистрируемого сигнала. Наличие охлаждаемого металлизированного экрана, помещенного на фоточувствительный слой МФ, приводит к сильному подавлению фоновой засветки, что позволяет увеличить время накопления, вследствие чего увеличивается детектируемый сигнал от излучения, проходящего через узкие щели.

Метод позволяет осуществлять спектральные измерения на разных длинах волн, что позволяет исследовать изменение ФРЛ и ЧКХ объектива с длиной волны. 